J. Andersen (ed.), Reports on Astronomy, Vol. XXIVA, 429-437.

(C)2000 IAU. Printed in the United States of America.

\title{
COMMISSION 41: HISTORY OF ASTRONOMY (A Joint IAU-IUHPS Commission)
}

\author{
(HISTOIRE DE L'ASTRONOMIE)
}

\author{
PRESIDENT: Steven J. Dick \\ VICE-PRESIDENT: F. R. Stephenson \\ ORGANIZING COMMITTEE: : S. M. R. Ansari, Wolfgang Dick, \\ Alex Gurshtein, Il. S. Nha, Wayne Orchiston, Edoardo Proverbio, \\ Woodruff T. Sullivan \& Xi Zezong
}

\section{GENERAL ACTIVITIES OF THE COMMISSION}

The membership of the Commission, as of its 50th anniversary in 1998, stands at 146 members and 19 consultants. In order to increase communications, during the report period the President issued six Newsletters to Commission members, consultants, and IAU officers. In a further attempt to increase communications, Commission 41 also instituted a web site (http://www.astro.uni-bonn.de/ pbrosche/iaucomm41/) in early 1998. This was largely due to the efforts of C41 Organizing Committee member Wolfgang Dick and the kindness of Professor Peter Brosche in supplying space. The site not only contains the Newsletters, meeting notices, and a list of members, but also the Bibliography on History of Astronomy, compiled by Ruth Freitag of the Library of Congress in Washington, D.C. The site also links to the history of astronomy site maintained for several years by the History of Astronomy Working Group of the Astronomische Gesellschaft, and now also maintained on behalf of Commission 41. These sites serve not only for better communication among Commission members, but also the broader history of astronomy community.

Slow progress was made on resolutions of previous General Assemblies. On the issue of preserving the sites associated with the Struve arc, Alan Batten represented Commission 41 at the Federation Internationale des Géomètres (International Federation of Surveyors) General Assembly in Brighton, U.K. On the issue of archives, Commission 41 joined an initiative of the Commission on Bibliography and Documentation of the Division of History of Science of the International Union of the History and Philosophy of Science. The goal is to make the scientific community more aware of the importance of preserving contemporary scientific archives. With his article on "The Royal Astronomical Society's Library and Archives", Peter Hingley, Librarian of the RAS, inaugurated a series of articles in the Commission 41 Newsletter on archives.

Work continued, albeit very slowly, on the General History of Astronomy, a long-term project of Commission 41. Volumes 2A and 2B, Planetary Astronomy from the Renaissance to the rise of Astrophysics, edited by Taton and Wilson, were published in 1989 and 1995, while volume 4A, Astrophysics and Twentieth-Century Astronomy to 1950, edited by Gingerich, was published in 1984. Work continues on Volume 3, Stellar Astronomy, Instrumentation and Institutions from the Renaissance to the Mid-Nineteenth Century, edited by Hoskin, and on volume $4 \mathrm{~B}$ edited by Gingerich. A new editor is being sought for volume 1 , Antiquity to the Renaissance.

In celebration of the year 2000 and the Millennium in 2001, Commission 41 joined with the U.S. Naval Observatory in sponsoring an around-the-world time ball drop on New Year's Eve for both years. Beginning in 1829 in Portsmouth, 1833 in Greenwich, and 1845 in the United States, time balls were historically an important means of visual time dissemination, and therefore an important part of the history of practical astronomy and navigation. At 
the beginning of the century, 19 were being dropped in the United States alone. As the new year sweeps around the world in 2000 and 2001 , participants were expected to drop time balls at midnight local time in New Zealand, Australia, South Africa, India, Sweden, the United Kingdom, New York City Times Square, and Washington, D.C. The drops were to be timed via the Global Positioning System, for which the U.S. Naval Observatory provides the time.

At the General Assembly in Kyoto, Commission 41 sponsored Joint Discussion 17 on "History of Oriental Astronomy"; details are reported in the IAU Highlights Vol. 11B, p. 693. A good deal of effort was spent during the report period organizing IAU Colloquium 178 on "Polar Motion: Historical and Scientific Problems", sponsored by Commission 41. The meeting, first suggested by Edoardo Proverbio at the Kyoto General Assembly, was held in Sardinia in September, 1999 on the occasion of the centennial of the first observations of the International Latitude Service. At the General Assembly in Manchester, Commission 41 is also sponsoring a Joint Discussion on "Applied Historical Astronomy", with F.R. Stephenson as chair of the SOC.

Among other International meetings in which Commission members participated were the Spring meeting of the Astronomische Gesellschaft on the occasion of its 200th anniversary, May 11-15, 1998, held in Gotha, Germany; the 1200th anniversary of Alfraganus, held in Uzbekistan, October 23-24, 1998; the Third International Conference on Oriental Astronomy, held in Japan, October 27-30, 1998; and the Fourth Biennial History of Astronomy Workshop at Notre Dame, Indiana, July 1-4, 1999.

Member deaths during the period included Heino Eelsalu, Derek Howse, Olaf Pedersen, and Helen Wright.

\section{RESEARCH OF COMMISSION MEMBERS}

This section is arranged geographically according to research location; of course, history of astronomy is a cross-cultural activity that knows no geographical bounds. The section is based on information provided by members, and represents only a sample of the full work of Commission 41 members. Full references to work mentioned here are given in the Select Bibliography at the end of this report, or in the Bibliography compiled by Ruth Freitag, posted at the Commission 41 Web site.

\subsection{China and Far East}

Prof. Dr. Liu Ci-Yuan, Shaanxi Observatory, Lintong, Shaanxi, President of Commission on History of Astronomy of the Chinese Astronomical Society, reports that research in history of astronomy is active in China, where astronomy has flourished for thousands of years. The "Xia-Shang-Zhou Chronology Project," which attempts to understand a possible solar eclipse event in the early Zhou dynasty (11th-9th century BC), is supported by the government. Liu Ci-yuan and colleagues have a number of papers in press on the records of solar eclipses in the Ming Dynasty (1368-1644 AD). Z. Weifeng at Shantou University has been working on research and analysis of ancient records of novae and comets in China, the relation between solar activity and climate, and the general reliability of ancient astronomical records of China. In addition, Professor Jiang Xiaoyuan reports that the first Chinese Department for the History and Philosophy of Science was established in March 1999 at the Shanghai Jiao Tong University. Numerous ancient astronomical records survive in China, and many experts work on them full or part time. Because of the language barrier, this research is often unknown, but the Chinese express hope that this can change in the near future. Commission 41 should do all it can to help realize this hope.

Il-Seong Nha, retired from Yonsei University, Seoul, Korea, and now honored as Professor Emeritus, has overseen the construction of a new museum in Yecheon Prefecture. The museum exhibits astronomical works available in Korea, China, Japan and other regions of the Far East, serves the public with written material for the study of the history of Oriental astronomy, and operates a $40-\mathrm{cm}$ reflecting telescope for professional and amateur research. 
A long-term project is the reconstruction of King Sejong's instruments, made in the 15th century.

\subsection{India}

Ansari and Pingree have been actively engaged in research on medieval India. For the first time, Ansari (1997a) has introduced unique astronomical manuscripts (in Arabic and Persian) of the Oriental Collection of the Salar Jung Museum (Hyderabad). These include a Commentary on âl-Khâzînî's Zîj [astronomical tables] by Shîrwan Shah, dated 1166 AD; Zîj-i Qutbî which is based on Zîj-i 'Ala'i and several Zîjes written in Deccan, which are translations of Sanskrit Siddhântas. In the category of theoretical astronomy, he enumerates particularly works of al-Tûsî, Birjandî, etc., and a commentary on an abridgement of Ibn Shâtir's Zîj.

A noteworthy work is the promotion of astronomy during 15 th -18 th centuries by Indian Sultans and Mughal emperors (Ansari 1997c). Besides several commentaries on standard works of Central Asian astronomers, a couple of Zîjes had been compiled and dedicated to the Indian Sultans/Emperors. Of note is the Zîj-î Muhammad Shâhî (ca 1730) in which Phillipe de La Hire's Tables have been adapted in the style of Central Asia. The recent papers of Pingree (1997, 1999) follow the translation of de La Hire's Tables into Sanskrit sources. Ansari (1997b) has discovered several manuscripts in Persian by Medieval Indian scholars, who attempted to transmit modern European astronomy into India. For the transfer of European astronomy to China, Japan and India, see also the comparative study of Ansari (1998 b).

Much work has been done in the history of astronomy in the ancient period of Indian history, using Sanskrit sources. Chatterjee (1997b, 1998) - an expert on calendaric astronomy - has discussed the calendars of Indonesian Bali and also that of Burma. But his major work is the thorough study of the controversy regarding the beginning of the Kâli era of Indian Yâgâ astronomy, which is usually taken as Feb. 26-27, 3102 BC. He argues also for three other possibilities, namely, Jan. 18-19, March 18-19 and April 16-17, as the beginning of the Kâlî era (Chatterjee, 1997a). In the same vein are also the series of papers by Hari (1997, $1998 \mathrm{a}, \mathrm{b} ; 1999)$, dealing with the mathematical rationale of the Yûgâ system, and of the extra-long sidereal and the solar years of the ancient Indian Siddhântic astronomy. Hari theorises also that the origin of the zero- point of the Indian sidereal astronomy/zodiac is to be sought in the Hindu astrology, particularly the philosophy of Tantra. In Indian practical astronomy there is the very exhaustive mathematical study of Padmânabha's Sanskrit treatise on the astrolabe, written in $1423 \mathrm{AD}$ (Ohashi, 1997) and the first ever Sanskrit treatise on astrolabe by Mahendra Sûrî, written in 1370, and on his followers (S. R. Sarma, 1999). Ohashi (1998) has also published his studies on the Indian cylindrical sundials, described in a few Sanskrit texts of 15th-16th centuries, with their English translation and modern commentary. Finally, we record here the text edition of the most significant Indian work: The Astronomical Treatise of Nîlakantha Sômayaji (1444-1545), along with two commentaries by the famous Indologist K.V. Sarma, with English translation by Narasimhan (Sarma, K.V. et al. 1998, Narasimhan, 1999).

Research carried out in history of astronomy and astrophysics of modern India may be found in the Indian Journal of History of Science. At the conclusion of the meeting "Indian Astronomy Through the Ages", held in Hyderabad on October 13, 1997, the much awaited Indian Society for the History of Astronomy (ISHA) was formed, with S. M. R. Ansari as President and B. G. Sidharth as Secretary. The Society will promote research in all aspects of the history of astronomy in general, and Indian and Asian astronomy in particular.

\subsection{Russia}

After the collapse of the USSR, a large-scale project to compose a realistic history of astronomy in Russia was successfully fulfilled under the aegis of Academician V.V. Sobolev (1915-1999) of St. Petersburg and Dr. A. A. Gurshtein of Moscow. The late Academician 
V. V. Sobolev served as the editor-in-chief. The coordinator of the project was Prof. A. K. Kolesov, of St. Petersburg University. This new historical narrative was performed without the ideological prejudice common for previous historical writings in the former Soviet Union. The result of this project has just been published as a collective monograph The History of Astronomy in Russia and the USSR, with fourteen authors. Janus-K Publishers issued the book in Moscow in 1999. The volume is in Russian and contains 592 pages. The circulation of the book is 1,000 copies. It is the most reliable source to check the historical development and accomplishments of Russian and Soviet astronomy.

The disciples of the well-known Soviet astronomer I. S. Shklovsky completed another important historical project, a new edition of Shklovsky's book Intelligence, Life, Universe. The title is a paraphrase of the famous Shklovsky treatise Universe, Life, Intelligence, originally published by the Soviet Academy of Sciences in 1962. In 1966 it was translated into English under the title Intelligent Life in the Universe. The new book includes a collection of memoirs of his sixty disciples and colleagues from both Russian and abroad. The book was issued at the end of 1996 .

Gurshtein has continued his large-scale project in the field of archaeoastronomical analyses of the genesis and evolution of the archaic constellations. Besides publications in Russian, his current results were published in a number of English-language presentations. Gurshtein and colleagues in Russia performed a broad circle of new archaeoastronomical investigations. They were published in two thematically oriented issues of Astronomical and Astrophysical Transactions (Vols. 17 and 19, 1998 and 1999), the English-language Russian magazine published by Gordon and Breach Science Publishers. The most noticeable achievement in this field is the publication of the Transactions of the international conference held in the Shternberg State Astronomical Institute (Moscow University), November 19-24, 1997. The coordinator of the project was Dr. E.N.Kaurov.

Under the editorship of Gurshtein, the Moscow astronomer A.V. Kozenko has issued the book Arthur Stanley Eddington (1882-1944) in Russian. D. D. Polojentsev, Pulkovo Observatory, St. Petersburg, has done work on the astronomer Numerov, and on astronomical aspects of an ancient Bolivian monument.

In Moscow, work was completed on the history of the founding of the Institute for Space Research, Russian Academy of Sciences, and scientific investigations within this research institution. The book will be printed at the beginning of the year 2000. Gurshtein has written a chapter on the history of the Department of the Moon and Planets.

\subsection{Estonia}

Izold Pustylnik, research associate at Tartu Observatory in Estonia, is working on the scientific legacy of Ernst Öpik. He reports that the paper on the history of astronomy at Tartu by Heino Eelsalu, recently deceased, will appear in the Journal of Astronomical History and Heritage.

\subsection{Europe}

During the past three years, research in history of astronomy in the Départment d'Astronomie fondamentale de l'Observatoire de Paris has concentrated on scientific cartography during the 17th and 18th centuries (Débarbat), astronomical instruments and archives (Débarbat, Poulle, Savoie), and general historical studies (Débarbat, Lerner, Pantin, Segonde, Toulmonde). Three exhibitions were organized at the Paris Observatory, involving S. Débarbat among the organizers: "Cassini-Huygens - Le temps d'un voyage" on the occasion of the launching of the Cassini-Huygens probe to Saturn (Sept. - Oct. 1997); "Mémoire d'argile - Mémoire vive", a confrontation between Babylonian and present astronomy (Oct. - Nov. 1998); and "Soleil - Tout feu - Tout flamme" (May - Aug 1999), on the occasion of the total solar eclipse to be seen from the North of France. All were open to the public. 
At the Institut d'Astrophysique de Paris, Simone Dumont has continued research, including an inventory of astronomical objects found in museums and elsewhere in France. The inventory is being carried out with the help of amateur astronomers and members of the Commission on History of Astronomy of the Société astronomique de France. R. Nadal, Observatoire Midi-Pyrénées, has co-authored articles on an astronomical fresco at the Ummayyad baths of Qusayr'Amra in Jordan, and a book containing the first French translation of the asterisms of Eratosthenes, including a catalog of 736 stars used by Eratosthenes to describe 42 constellations.

M. Stavinschi reports that interest in Romanian history of astronomy has lately increased due to the rich documentary material still unexplored, as well as the need to include Romanian astronomy in the world context. Recent investigations by Stavinschi, E. Botez and others have emphasized Romanian contributions to astronomy during the Middle Ages, including celestial mechanics, solar eclipse observations, and scientific personalities such as Chryssanthos Notaras and Constantin Gogu. The results were communicated at various international meetings organized in Romania and abroad, including the International Conference "Mysterium Cosmographicum 1596-1996" (Prague), the National Congress of the Scientific Societies in France (1996), JENAM 1997 (Thessaloniki, Greece), the Conference of the European Astronomical Society (Gdansk, Poland, 1997), JENAM 1998 (Prague), and the Spring Meeting of the Astronomische Gesellschaft (Gotha, Germany, 1998).

On 1 April 1998 the Bucharest Observatory of the Astronomical Institute celebrated its 90th anniversary. This constituted an opportunity for a retrospective look at the history of modern Romanian astronomy. Conferences on this topic were presented at various international and national scientific meetings, including the 4th Yugoslav-Romanian Astronomical Meeting (Belgrade), the 2nd Russian-Romanian Colloquium (St. Petersburg), JENAM 1998 (Prague), and the Annual Scientific Session of the Astronomical Institute (Bucharest).

In Germany The "Arbeitskreis" for the History of Astronomy met in connection with the meetings of the Astronomische Gesellschaft, with Wolfgang Dick as the main organizer. In 1998 the 200th anniversary of the first astronomical meeting of astronomers at Seeberg Observatory was celebrated by a special meeting at Gotha (May 11-15). P. Brosche was mainly engaged in the study of the German astronomy of the 18th and 19th centuries. The focus of his work is the astronomy in Gotha and F.X. von Zach.

A new series in history of astronomy, the Acta Historica Astronomiae edited by Wolfgang Dick and Juergen Hamel, is described below in the section on "Journals and Newsletters". W. Kokott has been researching the Alfonsine Tables, relying on the well-known past research by E. Poulle and others.

In Italy, E. Proverbio's major publication was the second volume of Giovan Stefano Conti: Lettere a Ruggiero Giuseppe Boscovich. Proverbio also continued work on the inventory of archives in Italy. F. Bònoli, Curator in Chief of the astronomical museum at the University of Bologna and Editor of the Giornale di Astronomia, has studied the astronomical researches in the Bologna "Studium" since Middle Ages, and the development of astronomical instruments and observations.

Anita Sundman, Stockholm Observatory, has included history of astronomy in her projects aimed at children and young people. In an educational television series (Utbildningsradion) in the spring 1999 , Swedish astronomical history was presented in order to attract the attention of primary school teachers with little training in science, and to encourage them to explore astronomy in class beyond the traditional textbooks.

In the United Kingdom, Michael Hoskin continues his work on the history of astronomy and field work in archaeoastronomy, and continues to serve as editor for Journal for the History of Astronomy. F. Richard Stephenson continued a variety of work in applied historical astronomy, including Earth's past rotation, historical supernovae and the accuracy and reliability of early measurements. His extensive investigations of Earth's past rotation, in collaboration with $\mathrm{Dr}$ L.V. Morrison, cover the period from 700 B.C. to the present day and mainly utilised pre-telescopic observations of eclipses observations from Babylon, 
China, Europe and the Arab world. There were two main aims of this research: (a) to delineate as accurately as possible the variation in the Earth's rotational clock error (Delta $\mathrm{T}$ ), as measured directly from the historical data; and (b) to use these results to define changes in the length of the mean solar day over the past 2700 years.

Early observations of "new stars", giving details of position, changing brightness, etc., are of particular significance in astrophysics, since no outburst of a galactic supernova has been definitely recorded since the invention of the telescope. In 1997, Prof Stephenson began to re-investigate the historical records of supernovae in collaboration with Dr D.A. Green of MRAO. In recent years, Green and others have made tremendous progress in investigating and cataloguing supernova remnants, while more historical information (Chinese and Arab) is slowly becoming available.

\subsection{North America}

The American Astronomical Society celebrated its centennial at its summer, 1999 meeting in Chicago, and Commission 41 members were heavily involved. D. Osterbrock served as overall Chair of the Centennial Committee; D. DeVorkin, chair of the Society's Historical Astronomy Division (HAD) through 1998, served as editor of a volume on The American Astronomical Society's First Century, and also delivered the opening keynote address at the centennial meeting; DeVorkin and S. Dick served on the HAD committee producing the centennial display, chaired by S. Schechner; and V. Trimble took over as HAD Chair in January 1999, and thus was chair at the time of the centennial.

S. Dick continued work on the history of the Naval Observatory and the history of the extraterrestrial life debate. D. DeVorkin completed his biography of Henry Norris Russell. T. Hockey, Secretary-Treasurer of the Historical Astronomy Division of the American Astronomical Society, published a volume on observations of Jupiter before photography. D. Osterbrock produced a history of Yerkes Observatory, and numerous articles, especially on W. Baade and S. Chandrasekhar. K. Pang produced articles on ancient eclipse records and long-term ephemerides. At Brown University K. Plofker continues her work on subjects related to the history of Indian astronomy. V. Trimble's work focused largely on the history of distance measurement in astronomy, especially the Hubble constant. C. Wilson has continued his work on the history of celestial mechanics, with contributions to the Storia della Scienza, the General History of Astronomy, and the Encyclopedia of Astronomy and Astrophysics.

In Canada, Alan Batten has been active in work on the Struve arc, and the new Journal of Astronomical History and Heritage.

\subsection{Australia/New Zealand}

W. Orchiston, a founding editor of the new Journal of Astronomical History and Heritage, continued research on a broad array of subjects related to the history of astronomy in Australia and New Zealand. With help from their co-authors, Raymond and Roslynn Haynes have jointly researched and published the history of Australian astronomy from Aboriginal astronomy to the present.

\section{JOURNALS AND NEWSLETTERS}

Two new journals in the field joined the venerable Journal for the History of Astronomy. Culture and Cosmos: A Journal of the History of Astrology and Cultural Astronomy issued its first volume in Spring/Summer 1997, with Nicholas Campion as editor. The journal had as one of its goals the study of the broader impact of astronomical ideas on human society. Following discussions at the IAU General Assembly in Kyoto, in June 1998 Commission 41 members, Wayne Orchiston and John Perdrix inaugurated the Journal of Astronomical History and Heritage. The journal publishes all aspects of astronomical history, including studies that place the evolution of astronomy in political, economic and cultural context. 
The first edition (vol. 14, number 1) of the journal Archaeoastronomy: The Journal of Astronomy in Culture appeared in June, 1999 under an expanded editorial board and a new publisher, the University of Texas Press. The journal, published since 1977, will maintain its high standards with a more regular publication schedule.

Wolfgang Dick and Juergen Hamel serve as editors of a new series of history of astronomy books known as Acta Historica Astronomiae. The series will comprise monographs, proceedings of conferences, general and thematic collections of articles, editions of manuscripts, bibliographies, inventories of astronomical archives, as well as graduate and doctoral theses. Reprints and translations of interesting historical works may also be published.

The Working Group for the History of Astronomy in the Astronomische Gesellschaft (AG) continued to issue newsletters in printed and in electronic form, including "Mitteilungen zur Astronomiegeschichte" (Nos. 9 to 14), "Elektronische Mitteilungen zur Astronomiegeschichte" (Nos. 16 to 42), "Electronic Newsletter for the History of Astronomy" (Nos. 16 to 38 ). Wolfgang R. Dick functioned as editor.

Steven J. Dick

President of the Commission

\section{SELECT BIBLIOGRAPHY}

Given below are only some of the highlights of the work of Commission members during the report period. A more complete bibliography is compiled by Ruth Freitag of the Library of Congress, and appears on the Commission $41 \mathrm{Web}$ site, in the Newsletter of the Historical Astronomy Division of the American Astronomical Society, and the Journal of Astronomical History and Heritage.

\section{References}

Ansari, S. M. R. 1997a. "Rare Arabic-Persian Manuscripts in Salar Jung Museum," Salar Jung Museum Biannual Journal (Hyderabad), vol.33-34 (1996-1997), 13-20.

Ansari, S. M. R, 1997b. "Modern Astronomy in Indo-Persian Sources," Proceedings of the Joint-Discussion-17: History of Oriental Astronomy, at the 23rd IAU General Assembly, held in Kyoto (Japan), Aug.25-26, 1997, in J. Andersen (ed.) Highlights of Astronomy vol.11B, pp 730-31. Kluwer Academic Publisher (Dordrecht) 1999.

Ansari, S. M. R. 1997c. "Promotion of Astronomy by Indian Monarchs during 15th -18th Centuries," Proceedings of the 600th Birth Anniversary Conference of King Sejong, held in Seoul (Korea), Sept.1, 1997, Ed. Changbom Park, to be published.

Ansari, S. M. R. 1998. "Post-Telescopic Astronomy in China, Japan and India," paper read at The Third International Conference on Oriental Astronomy from Calendar Scholars to Telescope, held in Fukuoka (Japan),Oct.27-30,1998, to be published in the Proceedings, Ed. Masanori Hirai.

Bònoli F., M. Calisi, P. Ranfagni. 1997. "Classification criteria for Historical Astronomical Instrumentation," in Atti del XVI Congresso Nazionale di Storia della Fisica e dell'Astronomia, a cura di P. Tucci, Centro Volta, Como, maggio 1996, p. 151-174.

Brosche, P. 1998. "Astronomie der Goethezeit", in Ostwalds Klassiker der exakten Wissenschaften Vol. 280 (Harri Deutsch, Thun und Frankfurt/M), 2nd edition.

Brosche, P. and H.-J- Tucholke (eds.). 1995. "Peter Andreas Hansen (1795-1874)," Sonderschriften der Akademie gemeinnûtziger Wissenschaften zu Erfurt, Vol. 27.

Brosche, P., W. R. Dick, O. Schwarz, R. Wielen (eds.). 1998. The Message of the Angles - Astrometry from 1798 to 1998 . Proceedings of the International Spring Meeting of the Astronomische Gesellschaft, Gotha, May 11-15, 1998. (Thun, Frankfurt am Main) Acta Historica Astronomiae, Vol. 3. 
Charvet, P. A. Zucker, J.-P. Brunet, and R. Nadal. 1998. Le Ciel. Mythes et histoire des constellations. Les Catasterismes d'Eratosthene. Paris, NiL editions, 1998

Chatterjee, S. K. 1997a. "A Note on Kâlî Era," Indian J. of History of Science, Vol.32, No. 1 (1997), 69-86.

Chatterjee, S. K. 1997b, "Balinese Traditional Calendar," Indian J. of History of Science, Vol. 32, No.4 (1997), 325-347.

Chatterjee, S. K. 1998. "Traditional Calendar of Myanmar (Burma)," Indian J. of History of Science, Vol. 33, No.2 (1998) 143-159.

DeVorkin, D. 1999. The American Astronomical Society's First Century (American Institute of Physics, Washington).

Dick, S. J. 1998. Life on Other Worlds: The Twentieth Century Extraterrestrial Life Debate (Cambridge University Press, Cambridge).

Dick, S. J., W. Orchiston and Love. 1998. "Simon Newcomb, William Harkness and the Nineteenth Century American Transit of Venus Expeditions.", J. History of Astronomy, 29, 221-255.

Dick, W. R., Zenkert, A.: Der Popularisator und der Forscher: Die Freundschaft von Bruno H. Bürgel und Paul Guthnick. In: M. Iven (ed.) "Seid nicht 'gerecht', sondern gütig!". Beiträge von und ueber Bruno H. Bürgel. Berlin, Milow, 1996, p. 58-79.

Dick, W.R.; Hamel, J. (eds.): "Beiträge zur Astronomiegeschichte," Bd. 1. Thun, Frankfurt am Main, 1998. 184 p. Acta Historica Astronomiae, Vol. 1

Dick, W.R.: "Astronomennachlaesse - Bewahrung und Erschliessung," in W.R. Dick, Jürgen Hamel (eds.), Beiträge zur Astronomiegeschichte, Bd. 1. Thun, Frankfurt am Main, 1998 , p. $170-175$.

Glass, Ian, Victorian Telescope Makers: The Lives and Letters of Thomas and Howard Grubb (Institute of Physics Publishing, Bristol and Philadelphia, 1997).

Gurshtein, A. A. "The Evolution of the Zodiac in the Context of Ancient Oriental History", Vistas in Astronomy, Vol. 41, Part 4, 1997, pp. 507-525. (This paper is the third part of a single investigation started with publications in Vistas in Astronomy in 1993 and 1995).

Gurshtein, A.A. "In Search of the First Constellations", Sky \& Telescope, Vol.93, 6, 1997 (June), pp. 46-50.

Gurshtein, A. A. "The Origin of the Constellations", American Scientist, Vol.85, 3 (MayJune 1997), pp. 264-273.

Hari, K. Chandra(1997), "True Rationale of Sûryasiddhânta", Indian J. of History of Science, Vol. 32, No. 3 (1997)183-190.

Hari, K. Chandra (1998a), "On the Origin of 'Kaliyugâdi' Synodic Super-Conjunction," Indian J. of History of Science, Vol. 33, No. 3 (1998) 193-201.

Hari, K. Chandra (1998b), "On The Origin of Sidereal Zodiac and Astronomy," Indian J. of History of Science, Vol. 33, No.4 (1998) 257-266.

Hari, K. Chandra (1999), "Intricacy of the Siddhântic Solar Year," Indian J. of History of Science, Vol. 34, No. 2 (1999), 133-144.

Haynes, R., R. Haynes, D. Malin and R. McGee (eds.), 1996. Explorers of the Southern Sky: A History of Australian Astronomy (Cambridge University Press).

Hearnshaw, J. B. 1997. The Measurement of Starlight: Two Centuries of Astronomical Photometry (Cambridge University Press).

Hockey, T. 1998. Galileo's Planet: Observing Jupiter Before Photography (Institute of Physics Publishing, Bristol).

Hoskin, M. (ed.), 1997. The Cambridge Illustrated History of Astronomy (Cambridge University Press).

Hoskin, M. (ed.), 1999. The Cambridge Concise History of Astronomy (Cambridge University Press). 
Narasimhan,V.S. (1999). "Tantrasangraha, Chapter VIII (English Translation): A Revised Version," Supplement to Indian J. of History of Science, Vol. 34, No. 2 (1999), 143-148.

Ôhashi, Yukio (1997). "Early History of the Astrolabe in India," Indian J. of History of Science, Vol. 32, No. 3 (1997), 199-295.

Ôhashi, Yukio (1998), "The Cylindrical Sundial in India," Supplement to Indian J. of History of Science, Vol. 33, No.4 (1998), 147-205.

Orchiston, Wayne, 1998. Nautical Astronomy in New Zealand: The Voyages of James Cook (Carter Observatory, Wellington).

Osterbrock, D. 1997. Yerkes Observatory, 1892-1950: The Birth, Near Death and Resurrection of a Scientific Research Institution (Univ. of Chicago Press, Chicago).

Osterbrock, D. 1995-1998. "Walter Baade: Observational Astrophysicist," J. History of Astronomy, 26 (1995), 1-32; 27 (1996), 301-348; 28 (1998), 283-316.

Osterbrock, D. 1996. "Chandra and his Students at Yerkes Observatory," J. Astrophysics and Astronomy, 17, 233-268.

Pang, K. 1998. "Astronomical Dating and Statistical Analysis of Ancient Chinese Eclipse Data," in J. Andersen (ed), Highlights of Astronomy, vol. 11B, 724-728.

Pang, K. 1998. "Postglacial Rebound and Other Influences of the Earth's Secular Rotation Rate, from Analysis of Ancient Eclipse Records," in Dynamics of the Ice Age Earth, Patrick Wu, ed. (Trans Tech Publications, Switzerland).

Pingree, David. (1997). "Philippe de La Hire at the Court of Jayasimha," Proceedings of the Joint-Discussion-17: History of Oriental Astronomy, at the 23rd IAU General Assembly, held in Kyoto (Japan), Aug. 25-26, 1997, Ed. J. Andersen, Highlights of Astronomy vol. 11B, p. 729, Kluwer Academic Publisher (Dordrecht) 1999.

Pingree, David. (1999). "An Astronomer's Progress," Proceedings of the American Philosophical Society, Vol. 143, No. 1 (1999), 73-85.

Proverbio, E., ed. 1996, 1998. Giovan Stefano Conti: Lettere a Ruggiero Giuseppe Boscovich, Vols. I and II (Rome).

Sarma, K.V. and Narasimhan, V.S.(1998), "Tantrasamhagraha of Nîlakantha Somayâji, Sanskrit," English Translation and Exposition in Terms of Modern Mathematics, Supplement to Indian J. of History of Science, Vol. 33, No. 1 (1998), S1-S48; No. 2, S49-S90; No. 3, S91-S146.

Sarma, S. R. (1999), "Yantrarâja: The Astrolabe in Sanskrit," Indian J. of History of Science, Vol. 34, No. 2 (1999) 145-158.

Stephenson, F. Richard, Historical Eclipses and Earth's Rotation, Cambridge, 1997.

Stephenson, F. Richard and Nha Il-Seong, 1997. Oriental Astronomy from Guo Shoujing to King Sejong. (Yonsei University Press, Seoul). 